NBER WORKING PAPER SERIES

\title{
A HISTORY OF PRICING POLLUTION (OR, WHY PIGOUVIAN TAXES ARE NOT NECESSARILY PIGOUVIAN)
}

\author{
H. Spencer Banzhaf \\ Working Paper 27683 \\ http://www.nber.org/papers/w27683 \\ NATIONAL BUREAU OF ECONOMIC RESEARCH \\ 1050 Massachusetts Avenue \\ Cambridge, MA 02138 \\ August 2020
}

I thank the Alliance for Market Solutions (AMS) for generous support of this research. I also thank Nathalie Berta, Elodie Bertrand, Maxime Desmarais-Tremblay, Steve Medema, Malcolm Rutherford, Kerry Smith, and participants in a 2020 virtual History of Economics Society session for valuable comments. The views expressed herein are those of the author and do not necessarily reflect the views of the National Bureau of Economic Research.

NBER working papers are circulated for discussion and comment purposes. They have not been peer-reviewed or been subject to the review by the NBER Board of Directors that accompanies official NBER publications.

(C) 2020 by H. Spencer Banzhaf. All rights reserved. Short sections of text, not to exceed two paragraphs, may be quoted without explicit permission provided that full credit, including () notice, is given to the source. 
A History of Pricing Pollution (Or, Why Pigouvian Taxes are not Necessarily Pigouvian) H. Spencer Banzhaf

NBER Working Paper No. 27683

August 2020

JEL No. B2,H23,Q2,Q5

\begin{abstract}
$\underline{\text { ABSTRACT }}$
The standard history of modern environmental economics often views it as an application of A.C. Pigou's theory of externalities, refined over the decades and applied to environmental problems in the 1960s, when the first detailed pro-posals for pricing pollution were outlined by Allen Kneese, Thomas Crocker, John Dales, and others. However, the historical literature has noted problems with this narrative, including a 30-year gap in discussions of such applications and few actual citations to Pigou. This paper offers a simple explanation for this puzzle: Namely, pollution pricing is not (necessarily) Pigouvian. It argues that the early applied literature on the topic was rooted more in questions about common property resources and increasing returns from developing natural re-sources. Both topics were treated by broad literatures by the 1960s, including distinctly American traditions not particularly associated with Pigou.
\end{abstract}

\author{
H. Spencer Banzhaf \\ Department of Economics \\ Andrew Young School of Policy Studies \\ Georgia State University \\ P.O. Box 3992 \\ Atlanta, GA 30302 \\ and NBER \\ hsbanzhaf@gsu.edu
}




\title{
A History of Pricing Pollution (Or, Why Pigouvian Taxes are not Necessarily Pigouvian)
}

\author{
H. Spencer Banzhaf
}

\section{Introduction}

From the publication of Rachel Carson's Silent Spring in 1962 to the first Earth Day in 1970, the 1960s witnessed a turning point in environmental thinking and politics. Social and political movements turned from the conservation of natural resources needed for production to a new post-war focus on the good life and aesthetic consumption (Hays 1982, 1987). Contemporaneously, economists turned from comprehending their own discipline in terms of "material welfare," to comprehending it in line with Lionel Robbins's definition in terms of tradeoffs and opportunity costs (Backhouse and Medema 2009a,b). This turn created space to redefine the relationship between economics and the environment to account for households' values for preservation, however immaterial or "spiritual" they might be, as the idea of "consumption" became ever broader and more abstract (Banzhaf 2019).

Numerous economists jumped into this space, from Robert Solow and Joseph Stiglitz to Kenneth Boulding and Nicholas Georgescu-Roegen on questions of sustainability, from Kenneth Arrow to James Buchanan on externalities, or William Baumol, Wallace Oates, and Martin Weitzman on pollution pricing, among many others. But of all economists working on pollution pricing in the era, Allen V. Kneese (1930-2001) was the widely acknowledged leader. In The Economics of Regional Water Quality Management (1964), Kneese, an economist at Resources for the Future, introduced detailed proposals for "effluent charges" on emissions of pollutants into waterways. Shortly thereafter, Thomas Crocker (1966) and John Dales (1968a) introduced proposals for trading pollution rights, later known as the tradable permit or cap-and-trade approach.

The conventional narrative is that such work picked up where A.C. Pigou had left off some 30 years before in The Economics of Welfare (1932) (Berta 2019, Pearce 2002, Sandmo 2015, de Steiguer 2006). According to this way of thinking, Pigou had developed his theory of external economies and diseconomies in the first third of the $20^{\text {th }}$ Century using environmental as well as other examples. Though the idea lay neglected for some decades, when economists began to take 
up environmental issues in the late 1950s and 1960s, they picked up Pigouvian models and policy tools (the familiar "Pigouvian tax") to address them. A corollary to this theory is that Ronald Coase's "Problem of Social Cost" (1960) was an early response to this trend, introducing a rival approach of property rights and trading in lieu of corrective pricing. Environmental economists and their policy proposals can then be classified by the extent to which they are Pigouvian or Coasean or some hybrid.

In this paper, I argue that, while this Pigouvian box was undeniably an important source for economists in the 1960s thinking about externalities, it was but one of many. Nobody likes neat boxes, and it is cheap work historically to blur their boundaries, but logical categories are necessary. My claim here is not just that the "Pigouvian" and "Coasean" boxes are too neat, but that we have missed entire boxes altogether, and perhaps the ones at eye level on the shelf. In the US, first-generation specialists in environmental economics had been trained in agriculture and natural resources and/or in regional development, fields which had their own well-established canon covering questions of land use, property rights, indivisibilities, incentives, and so forth, much of it bearing American institutionalist marks stamped by Richard Ely and his students. Trying to understand such work in terms of debates between Cambridge and LSE is a categorical mistake.

As Medema (2020a) has recently emphasized, one problem with the conventional narrative is that it's impossible to trace an unbroken line from Pigou to the environmental work of the 1960s. In the intervening decades, Pigou's ideas on external (dis)economies had evolved into today's concept of externalities, but without much reference to real-world applications. As Medema tells the story, the line was lost but then reconnected: When environmental applications began to loom larger, the revised Pigouvian theory was simply "grafted into" the emerging field of environmental economics. In this paper, I offer a different explanation. In the first half of the $20^{\text {th }}$ Century, Pigou's ideas about the divergence between the private value of investments and social net product, though important, never really were as unique as the later literature came to imply. Though the moniker "Pigouvian" was adopted around 1970, the name should not be confused with hereditary lineage.

Though there were continuous lines of thought running through the period in American economics, the lines run back to the economics of land use and resource development, not to Pigou. 
These traditions had developed their own distinctive schools of thought about the economies of scale of resource development and the poor incentives of open access to common resources.

Section 2 of this paper gives an overview of Pigou's discussion of social benefits and costs as well as the secondary literature that has by now well established the difficulties with linking his work to the emerging field of environmental economics in the 1960s. Section 3 introduces the work of Allen Kneese, the leading expert in the era on pollution pricing, and discusses its relationship to Pigou, Coase, and other sources; Section 4 similarly introduces the work of Thomas Crocker and John Dales on tradable pollution rights. Section 5 situates their work in the historical context of agricultural and applied resource economics.

\section{The Pigouvian Tradition}

The standard history of environmental economics begins with the work of A.C. Pigou (1877 1959), the Cambridge economist famous for his theory of the potential divergence between private benefits and costs (values that are captured by markets) and social benefits and costs. ${ }^{1}$ Following Bator $(1957,1958)$, economists today would refer to these effects-especially as they relate to environmental problems-as "externalities." Externalities are famously hard to define, but, roughly speaking, they represent an unpriced effect on third parties, uninvolved in an economic transaction or decision. ${ }^{2}$

In The Economics of Welfare (1932), Pigou identified three groupings of situations where he thought there is a divergence between private and social benefits and costs. Pigou's second grouping is the one closest to what we now think of as externalities. This represents a situation where

One person A, in the course of rendering some service, for which payment is made, to a second person $\mathrm{B}$, incidentally also renders services or disservices to other persons ...., of such a sort that payment cannot be exacted from the benefited parties or compensation enforced on behalf of the injured parties. (p. 183)

Pigou gives several examples of such services that certainly could be read as a kind of proto-

\footnotetext{
${ }^{1}$ For background, see Medema (2009, Ch. 3), Aslangeigui and Oakes (2015), and Kumekawa (2017).

${ }^{2}$ Classic attempts to wrestle with the definition of externalities include Viner (1932), Meade (1952), Scitovsky (1954), Bator (1958), Buchanan and Stubblebine (1962), and Arrow (1969). For historical overviews of the concept, see Papandreou (1994), Lagueux (2010), Berta (2017), and Medema (2020a).
} 
environmental economics. "Uncompensated services are rendered," he says,

when resources are invested in private parks in cities; for these, even though the public is not admitted to them, improve the air of the neighbourhood. The same thing is true - though here allowance should be made for detriment elsewhere — of resources invested in roads and tramways that increase the value of the adjoining land. ... It is true, in like manner, of resources devoted to afforestation, since the beneficial effect on climate often extends beyond the borders of the estate owned by the person responsible for the forest. ... It is true of resources devoted to the prevention of smoke from factory chimneys: for this smoke in large towns inflicts a heavy uncharged loss on the community, in injury to buildings and vegetables, expenses for washing clothes and cleaning rooms, expenses for the provision of extra artificial light, and in many other ways. (p. 184)

Pigou gives other examples as well, including Mill's example of a lighthouse aiding ships; private lamps at house doors, which illuminate the street; and basic scientific research. Thus, Pigou's discussion seems like a natural source for economic thinking about environmental problems.

Though Pigou's importance to environmental economics cannot be denied, a story about environmental economics being developed through direct applications of Pigou's theory of externalities runs into three difficulties. First, Pigou's analysis was much wider ranging than today's theory of externalities, so it was not obviously focused on environmental harms and similar issues. As already noted, Pigou considered three groupings of effects. The first includes situations where productive investments might potentially be made by people who do not own the instrument of production being maintained or enhanced. A notable example is tenant farmers, who do not have the full incentive to enhance the fertility of the land they are renting; indeed they have an incentive to let it depreciate rapidly in the years before their lease expires (Pigou 1932, pp. 174-83).

Pigou's third grouping comprises situations, discussed earlier by Alfred Marshall, where there are increasing or decreasing returns at the industry level or even between industries (pp. 21328). This portion of Pigou's theory was the most controversial, and Pigou steadily revised his analysis, retreating from some of the stronger versions of the argument that he had espoused earlier in his career, which involved external effects on land and resource rents (McDonald 2013, Aslanbeigui and Oakes 2015, Medema 2020a). Notably from the standpoint of the history of American resource economics, much of this was a transatlantic debate, with Pigou's ideas mediated through Young (1913, 1928), Knight (1924), Viner (1932), and Ellis and Fellner (1943) as well as Meade (1952). Even so, in the fourth edition of The Economics of Welfare (1932), Pigou gave the 
example of the cotton industry, which when it operates on a larger scale takes on a structure of increasing specialization among firms, with some firms weaving and some spinning, some spinning fine counts and others course. In such cases, he argued, investment enters the industry to the point where the marginal firm is indifferent to entering, but nevertheless its entrance increases economic rents for other firms, thus creating a divergence between the private value of investment and the social net product.

Pigou's work spawned a large literature sorting out the nuances of these three situations and how they inter-relate. ${ }^{3}$ While this is not the place to focus on the subtleties of those relationships, it is enough for my purposes to note that, first, because he was writing a large volume about welfare, Pigou's discussion is inherently synthetic, so not all the material found in it is uniquely his. Second, while in retrospect it is easy to pick out the bits that resemble a proto-environmental economics, when taken as a whole, at the time Pigou's discussion did not obviously apply to environmental problems.

The second difficulty with a linear history from Pigou to modern environmental economics is that, as emphasized previously by other observers, while it is the second of Pigou's groups that today is most closely associated with the idea of "externalities," that actually was the group most ignored in the literature until at least the late 1950s, with passing references to smoking chimneys or traffic congestion viewed as "curiosities" or, in Baumol's (1952) words, "freakish exceptions." 4 Two decades later, with environmental economics on a swift assent, Kneese commented:

Environmental pollution has existed for many years in one form or another. It is an old phenomenon, and yet in its contemporary forms it seems to have crept up on governments and even on pertinent professional disciplines such as biology, chemistry, most of engineering, and, of course, economics. A few economists, such as Pigou, wrote intelligently and usefully on the matter a long time ago, but generally even that subset of economists especially interested in externalities seems to have regarded them as rather freakish anomalies in an otherwise smoothly functioning exchange system. Even the examples commonly used in the literature have a whimsical air about them. We have heard much of bees and apple orchards and a current favorite example is sparks from a steam locomotive- this being some eighty years after the introduction of the spark arrester and twenty years after the abandonment

\footnotetext{
${ }^{3}$ For discussion, see Lagueux (2010), McDonald (2013), Berta (2017), and Medema (2020a).

${ }^{4}$ On this point, see Lagueux (2010), Lane (2014), Sandmo (2015), Berta (2020a), and especially Medema (2020a).
} 
of the steam locomotive. (1971a p. 2)

In other words, there was a large gap between the time Pigou wrote about what we would now call externalities and references to it in the literature, at least by those that took it seriously. This gap raises the possibility that other currents were at work during the period.

The third-and most surprising — difficulty with the Pigouvian origin of environmental economists is that, even as economists like Meade, Scitovsky, Bator, and Buchanan did begin to talk more about "externalities" and environmental examples, actual specialists in environmental economics hardly referenced Pigou at all until about 1970. When environmental economists in the 1960s did refer to Pigou, it usually was limited either to welfare economics very broadly or to Pigou's discussion of our defective telescopic faculty and the resulting excessively rapid depletion of natural resources. ${ }^{5}$ Even more to the point, they rarely mentioned him when discussing pricing access to environmental resources, not only for "green" uses like recreation, but even for "brown" uses like depositing wastes. Though today economists might naturally refer to such prices as "Pigouvian taxes," at the time they were known simply as "effluent charges" (e.g. Kneese 1964), without making a connection to Pigou. As I show in the next section, the Pigouvian terminology didn't enter widespread circulation until the 1970 s.

Of course, one possible reason economists might not have attributed their ideas to Pigou is that his ideas had become so embodied in economics, so taken for granted, that they did not warrant citation. ${ }^{6}$ If it was merely the negative evidence of what environmental economists did not say, that explanation might be satisfactory. However, as I show in the following sections, the arguments used by first-generation environmental economists, along with the hints from those references that they do make, suggest stronger links to the agricultural economics literature and institutionalist analysis of common property.

\section{Allen Kneese and Effluent Charges}

In the 1960s, Allen V. Kneese (1930-2001) was the widely acknowledged leader in the economics

\footnotetext{
${ }^{5}$ E.g., Krutilla (1967). See Collard (1996) and Kula (1998 Ch. 6) for historical discussion of Pigou's views on resource depletion.

${ }^{6}$ Medema (2020a) discusses some evidence in support of the idea of an "oral tradition" as mentioned by Coase (1960). Kneese himself noted that "Economists have long held that technological spillovers can be counteracted by levying taxes on the unit 'responsible' for the diseconomy and by paying a subsidy on the 'damaged' party" (1964 p. 56), indicating such a tradition looms in the background.
} 
of pollution pricing. ${ }^{7}$ Extensively cited, Kneese's Economics of Regional Water Quality Management (1964) and other works were considered the first systematic treatment of the topic and certainly the most definitive. ${ }^{8}$

Kneese earned his $\mathrm{PhD}$ in economics from Indiana University, with a dissertation on market power and exclusive dealing in the farm machinery, automobile, and petroleum industries (Kneese 1956). After graduating, he worked at the University of New Mexico and at the Federal Reserve Bank of Kansas City, where he first turned to researching water resources problems in the American West. At what was still an early stage in his career, Kneese moved to Resources for the Future (RFF) in $1961 .^{9}$ He established himself as a leader in the field, artfully using RFF grants and conferences to shape the community's research agenda. He was a founding editor of the journal Water Resources Research. Later, as environmental economics, alongside other sub-disciplines, was formalizing its institutions in the 1970s, Kneese was front and center, serving as the first president of the Association of Environmental and Resource Economists and founding editor (along with his collaborator, Ralph d'Arge) of its flagship publication, the Journal of Environmental Economics and Management (JEEM).

Kneese's first forays into the economics of water resources addressed the traditional problem of developing them as inputs into material production, particularly in the context of water shortages in the American West (Kneese 1960). Like other works at the time on this surging subject, ${ }^{10}$ Kneese adopted a welfarist perspective on the problem, discussing "normative problems in the evaluation of water resources development projects." As a logical point of departure, he began with what he characterized as Pigouvian welfare economics, essentially the interpretation of market prices as marginal social values generally, as in Pigou's national dividend, but not the divergence of private and social values specifically. But then Kneese's next move was to dismiss this older Pigouvian approach as too simplistic in its treatment of interpersonal comparisons of

\footnotetext{
${ }^{7}$ See Nishibayashi (2019) for a historical discussion of Kneese and his work.

${ }^{8}$ Fort et al. (1959) presented an earlier proposal for a "smog tax," published as a RAND report, but it did not circulate widely and appears to have been forgotten until its rediscovery ten years later. For those interested in trivia, the report was the first "publication" for both William Niskanen and William Sharpe.

${ }^{9}$ See Kneese (1988) for a brief autobiographical statement, including a summary of early intellectual influences.

${ }^{10}$ E.g. Eckstein 1958, Krutilla and Eckstein 1958, McKean 1958, Hirshleifer, De Haven, and Milliman 1960.
} 
utility, it now being superseded by the "new welfare economics" of Hicks and others. ${ }^{11}$

Kneese also identified Pigouvian external economies as a key concept in normative project evaluation, but only as refined by Ellis and Fellner and others. Interestingly, at this stage he barely mentioned pollution in connection to this idea. Instead, he emphasized external economies (more so than diseconomies) from increasing the scale of resource development. For example, surfacewater irrigation might recharge aquifers used by neighboring farms for irrigation; upstream storage improves the efficiency of down-stream hydro-electric power; etc. Most generally, an expanding market in a rural area may contribute to an increase in regional economic efficiency by facilitating the division of labor (1960 pp. 311-12).

It was around this time that Kneese moved to RFF. As discussed in Banzhaf (2019), RFF was evolving at this time from its initial emphasis on the scarcity of natural resources needed for development and economic growth to a new one on the scarcity of environmental amenities. Hired by John Krutilla and Irving Fox, Kneese joined RFF as part of this pivot, leading up a new research program on water quality.

After his move to RFF, Kneese turned immediately to the study of water pollution, publishing initial thoughts on the subject (Kneese 1962, Kneese and Nobe 1962). Kneese wanted to apply a welfarist, benefit-cost perspective on the pollution problem, but he also wanted to forego the traditional approach of evaluating a policy already formulated by engineers into one that embeds the economics into the design of multipurpose development of entire river systems. In this, Kneese was following recent trends including work by his RFF colleague John Krutilla (Krutilla and Eckstein 1958) and especially by the Harvard Water Program (Maass et al. 1962), which Kneese later singled out as the "apogee" of work on the design of multiple use water systems (Kneese 1988). ${ }^{12}$

Kneese identified several characteristics of water resources that raised unique policy problems, including, among others:

1. Water resources are highly mobile and highly variable in quantity and quality in time and space, so water quality must be treated probabilistically;

\footnotetext{
${ }^{11}$ Likewise, John Krutilla, Kneese's long-time RFF colleague, depicted his own career retrospectively as having played out against the backdrop of just these issues (Krutilla 1981).

${ }^{12}$ See Banzhaf (2009) for further discussion of the Harvard Water Program and its relationship with RFF.
} 
2. They do not respect political boundaries;

3. They have multiple purposes, provided by the same resource simultaneously and/or sequentially;

4. A particular use provides benefits and imposes costs on different groups separated geographically;

5. They are (at least nominally) publicly owned

(Kneese and Nobe 1962 pp. 46-7). According to Kneese, distortions from the marginal-benefitequals-marginal-cost rule arise because, given these realities, private producers cannot enter the market and produce socially desirable value while still covering their costs. Economies of scale, indivisibilities in jointly supplied outputs, and external economies and diseconomies all impede the potential to collect sufficient revenue. Examples of such external effects include the recharging of aquifers resulting in land drainage problems; decreases in dissolved oxygen resulting in fish kills; hydroelectric power altering stream flow, which in turn hinders navigation; and irrigation which results in sedimentation of water, thereby increasing treatment costs for municipalities. Thus, whereas Kneese's RFF colleague Marion Clawson wrestled with how to think about measuring benefits of investments in public lands, in a paradigm where norms were determined by the revenues that could be raised in a realistic market institution (Banzhaf 2010a), here Kneese thinks about the problem in reverse: Realistic revenues fails to capture the normative benefits, as determined outside the market by an economic model of optimization.

In Kneese's view, all this creates a role for planning, but logically consistent plans would require two forms of aggregation. First, geographically, the planning area must be sufficiently wide to encompass these and other relevant effects, so that upstream and downstream tradeoffs were captured in the planner's field of vision. Second, to trade off the competing ends of water resources (e.g. for deposition of wastes upstream or recreation downstream), one would have to aggregate across services. Obviously, Kneese argued, one cannot maximize a mix of different services measured in incommensurate physical units. So "the question of weighting alternate physical outputs in some meaningful commensurable manner inevitably arises and the weights logically must represent some measure of relative social worth" (p. 449). If pollution damages and abatement costs both are denominated in dollars, then marginal costs can be equated across abatement alternatives and to marginal damages of foregoing abatement. This could be achieved through "a system of charges and bounties" (p. 459). 
This system of effluent charges, mentioned only in passing in 1962, evolved into the centerpiece of Kneese's best-known work, The Economics of Regional Water Quality Management (1964), which was further expanded and revised in collaboration with Blair Bower, an engineer, in 1968 as Managing Water Quality: Economics, Technologies, Institutions. This work was perceived at the time to be the definitive statement of pollution pricing. As indicated by the subtitle of the 1968 book, at the outset it is evident that Kneese combined (i) the economic logic of external diseconomies and property rights; (ii) a materials balance logic of production, residual wastes, and transport of those wastes across space; and (iii) institutional concerns. As he wrote in the introduction of Regional Water Quality Management,

[The] economic institutions on which we customarily rely to balance costs and returns - the interaction of market forces in a private enterprise system — do not perform this function satisfactorily for waste disposal. Aesthetic nuisance in a stream destroys public values that are not marketable. In deciding how to dispose of its wastes, an upstream firm or city is not forced to take into account the costs imposed upon downstream water users.... Under some circumstances there are economies of scale in waste disposal that cannot be realized by an individual firm or city acting independently.

Because of these features of waste disposal, market forces are supplemented in a variety of ways. Appeals are made to civic responsibility.... Damaged parties may resort to adversary proceedings in courts of law. Financial inducements to encourage waste treatment by municipalities are offered by the federal government, and storage to augment low flows is provided at federal expense. .... But in the application of these practices there has not been a systematic balancing of costs and returns to achieve optimum benefits.... (p. 4)

In short, when market institutions fail to equate marginal costs and benefits of an activity, other institutions must take their place. But so far, he said, the array of regulatory responses, while perhaps moving the outcome in the right direction, were not efficient.

Kneese's preferred solution was a system of spatially differentiated effluent charges, ideally set at the marginal damages of emissions. ${ }^{13}$ Although he was optimistic about progress being made in the nonmarket valuation of pollution damages, especially in the area of outdoor recreation

\footnotetext{
${ }^{13}$ Kneese also considered subsidies (or bounties) for pollution abatement as an option, but felt it raised additional implementation issues. For example, if under optimal resource allocations a firm reduced its pollution by exiting the market, the owners of that non-existent firm would still have to receive their subsidy. The extent of the symmetry between pollution taxes and subsidies became an active research question around this time. See Baumol and Oates (1975) for a literature review from the period and summary.
} 
(see Banzhaf 2010a, 2018) and environmental health (e.g. Weisbrod 1961), he acknowledged that it was not yet practical to estimate the marginal damages from pollution.

Accordingly, Kneese proposed the alternative of ambient quality standards, in which the authority mandates a minimum level of water quality to be maintained downstream. Discussing the duality between prices and quantities, he argued that this standard too could best be met by charging fees equal to the marginal costs of meeting it. Although not equating them to marginal damages, this more pragmatic approach would still have the virtue of equating the marginal costs of reducing downstream injuries across various margins of adjustments (reductions in the output of dirty goods, changes in the production process, end-of-pipe controls, water storage and dilution, etc.). Kneese proposed a trial-and-error approach that, essentially, involved groping for the unknown "supply" of pollution abatement. That is, the regulator would impose initial prices on upstream pollution emissions (effluent), observe how much pollution was reduced at various downstream points, and then adjust the prices to meet the target. Applications using Kneese's approach soon followed, demonstrating the potential cost savings using linear programs to find least-cost solutions (Johnson 1967, Davis 1968).

From his discussion, it might appear that Kneese's vision was a grand plan requiring the superior knowledge of a social planner, including marginal damages and marginal abatement costs across various activities all spatially differentiated. In fact, Kneese disavowed any such interpretation. To the contrary, he stressed the fact that with effluent charges, the market - not a plannerwould find the way to reduce pollution (or just pay the charge if pollution reductions were too expensive). In a static world of given abatement costs, the charges provided the incentive for firms to select those abatement technologies that were most cost-effective. In the long run, they provided dynamic incentives to find new ways to reduce pollution at lower cost.

\section{Effluent Fees and Pigouvian Taxes}

Viewing the history of economics in retrospect, it is natural to interpret Kneese's effluent fees as an application of Pigouvian remedies to market failures, albeit one enriched with technical and institutional details (Berta 2019, 2020a, Pearce 2002, Sandmo 2015, de Steiguer 2006). But, as such histories themselves have noted, this story raises the question of, first, why there a large lacuna in the Pigouvian literature on environmental externalities from the 1930s to '60s and, sec- 
ond, why, when it supposedly re-appeared, Pigou was not actually much mentioned in the environmental literature.

Kneese's work epitomizes these gaps between Pigou and pollution pricing. After his discussion of normative problems in evaluation of water development problems (Kneese 1960), which discussed Pigouvian welfare economics as a stage in utilitarian thinking generally, Kneese did not cite or mention Pigou at all until the end of the decade. Kneese was not alone in this. According to JSTOR, the term "Pigouvian tax" (or close variants ${ }^{14}$ ) appeared first in Buchanan and Stubblebine (1962) and only 12 times in the decade of the 1960s. Nor can this be attributed to a general disinterest in the topic. Until about 1972, others working on similar topics or commenting on policy proposals to levy fees on pollution-from Nobel laureates to applied

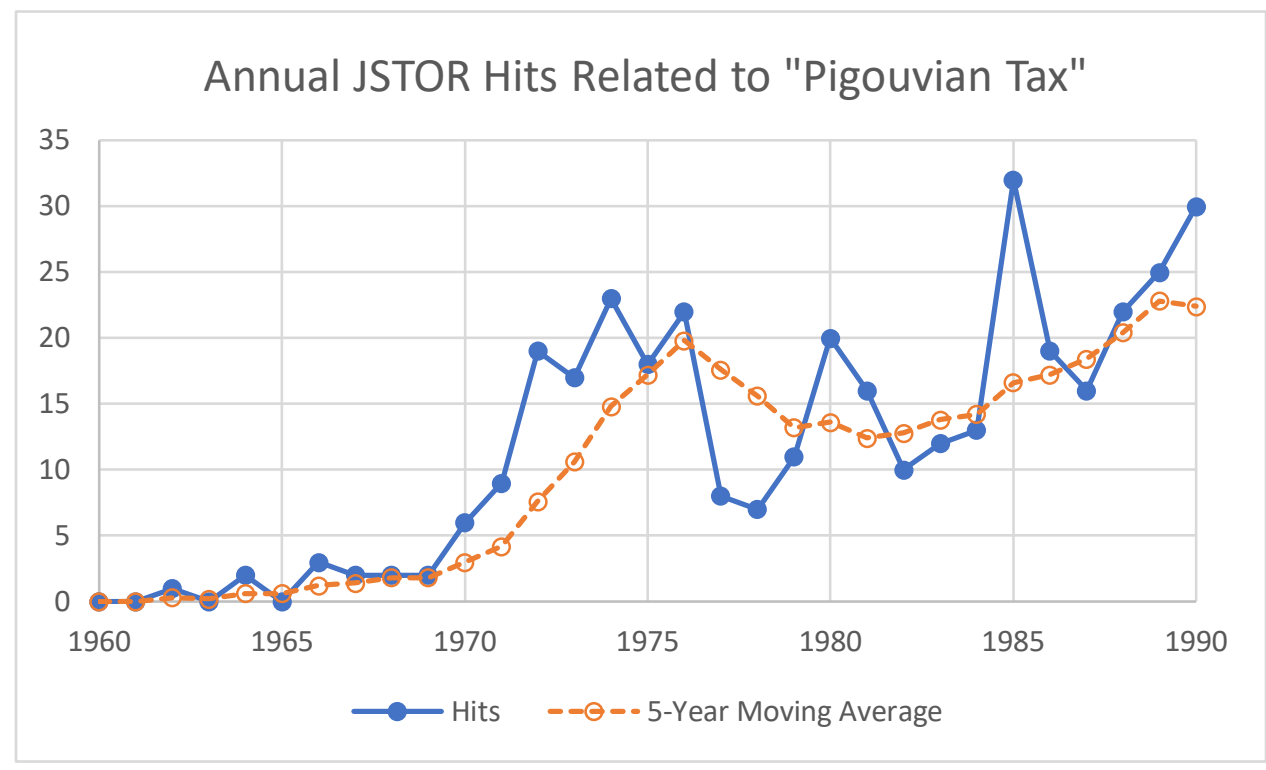

practitioners_cited Kneese without mentioning Pigou, apparently treating his work as original. A Google Scholar search yielded only 65 hits mentioning Kneese and Pigou between 1962 and 1972, 982 hits mentioning Kneese but not Pigou, and 2,110 mentioning Pigou but not Kneese. ${ }^{15}$ So it appears that, at this time, the environmental literature on effluent charges and the Pigouvian

\footnotetext{
${ }^{14}$ Including "Pigovian" instead of "Pigouvian," "taxes" as well as "tax," and "Pigou" in conjunction with "corrective tax" or "effluent fee" or "effluent charge."

${ }^{15}$ Examples of prominent papers or authors citing Kneese but not Pigou include Crocker (1968), Dales (1968a,b), Davis (1968), Freeman and Haveman (1972), Johnson (1967), Mills (1966), Montgomery (1972), Ostrom and Ostrom (1965), and Solow (1972). The search was conducted on May 28, 2020 and excluded hits where Kneese was author or editor.
} 
literature on externalities were operating in quite distinct spheres.

At the turn of the decade, the term "Pigouvian tax" appeared in Baumol's review of Buchanan's Cost and Choice and in Baumol and Oates (1971). In that paper, Baumol and Oates provided a formal proof of Kneese's argument that an effluent fee could induce the least-cost method for meeting an arbitrary environmental objective, even if it was not optimal in the sense of equating marginal costs to marginal damages (see Berta 2020a for discussion). In doing so, they described Kneese's work as part of a "Pigouvian tradition." At this point, references to Pigou increased rapidly (see figure). By the end of the decade, Kneese himself was putting it in these terms (Ayres and Kneese 1969, Kneese and Mäler 1973) and it was enshrined in textbooks and prominent literature reviews (Baumol and Oates 1975, Fisher and Peterson 1976). Thus, the idea that pollution prices are almost synonymous with "Pigouvian" may have been a reinterpretation first made by Coase and Buchanan, and then consolidated by Baumol and Oates. ${ }^{16}$ But it was a reinterpretation of an existing body of work already developed separately from worries about Pigou's place in the canon.

Rather than talk about his approach as Pigouvian, Kneese was, ironically, more apt to talk of it in Coasean terms (Nishibayashi 2019). In Regional Water Quality Management, his opening moves in his economic analysis (after a chapter on "technical and engineering facts") were to take the reader through a tour of market efficiency, with external diseconomies presenting a potential exception to the superiority of markets. He then quickly introduced Coasean (1960) bargaining as one possible way for markets to consider downstream costs of waste disposal (pp. 40-47), making this one of the first treatments of Coase's negotiating result in the environmental economics literature. $^{17}$

Interestingly, Kneese interpreted the negotiating result in terms of Coase's earlier logic from the "Nature of the Firm" (Coase 1937). Wrote Kneese,

When such technological links are "internal" to a decision unit, the result may be considerably different than if they are external. To take a simple example, a farmer may find that a small stream on his property will irrigate either an upstream plot A

\footnotetext{
${ }^{16}$ Medema (2020a) suggests that, ironically, it was perhaps Buchanan's and Coase's attacks in the 1960s on Pigouvian economics that built up the idea that the approach was inherently Pigouvian.

${ }^{17}$ See Medema (2014a,b, 2019) on the Coase theorem in the environmental economics literature of the 1960s and '70s, including Kneese's role.
} 
or a downstream plot B, but not both. .... In deciding whether to irrigate plot A, the farmer will consider the return lost on plot B, and plot $A$ will be irrigated only if its return is higher. Consequently, the resource will be allocated in the way that maximizes the value of production. If, however, plot B is on another farmer's land and the owner of plot A cannot sell his right to the water, the owner of plot A will not consider the return lost on plot B in determining whether to irrigate plot A. If plot B actually presents the superior productive opportunity, failure to irrigate it because the water is preempted upstream is a technological external diseconomy.

Now suppose that the owner of plot A can sell his right to the water and that the farmer owning plot $\mathrm{B}$ can afford to, and has an incentive to, pay more for the water than it is worth if applied on plot A. In this case, the efficient result would once again be produced. (p. 41)

In this way, Kneese believed the question of external diseconomies is intrinsically intertwined with questions of property rights and market institutions, so it cannot be examined solely through technical relationships. Erstwhile diseconomies can be internalized either through negotiation (Coase 1960) or through merger (Coase 1937), but either way the logic is similar. ${ }^{18}$

Because of high transactions costs, Kneese thought that Coase's negotiation result was unlikely to be relevant to water pollution problems. He also thought that the idea of a single firm internalizing all the services provided by water within a relevant drainage basin was as undesirable as it was unrealistic. Operating so many enterprises would have high administrative costs. Additionally, the benefits of internalizing externalities would be at least partially offset by the creation of monopoly power.

Nevertheless, Kneese found this notion of the basin-wide firm to be useful as an organizing principle, and it was an idea he would continue to revisit throughout his career (e.g. Kneese and Schultze 1975). As with the single farm with plots A and B, Kneese suggested the basin-wide firm would be a "natural decision unit" in the sense that it would internalize externalities. It could own upstream plants that benefit from releasing wastes, but also charge levies for downstream recreation use. Then the firm will equate the marginal costs of pollution control at the upstream plants to one another, but also to the marginal damages of effluent on foregone recreation values. In making this point, Kneese drew explicitly on Coase (1937) as well as Stigler (1946) and Davis

\footnotetext{
${ }^{18}$ See Bertrand (2015) for the connections between Coase's two classic articles; her discussion is highly pertinent to Kneese's treatment.
} 
and Whinston (1962). ${ }^{19}$

Kneese drew three lessons from this artifice of the basin-wide firm. First, administrative agencies ideally would operate at the geographic scale of the water basin. In this way, they would have jurisdiction over all the relevant effects, internalizing them. Second, they should think in terms of economic incentives, such as those provided by effluent charges. Third, like a firm, they should think in terms of maximizing economic value, by minimizing costs and making economic tradeoffs between upstream and downstream activities. In this sense, Kneese was extending the logic of Coase's theory of the firm, but whereas Coase limited the institutional choice to either expanding the boundaries of the firm or trading among firms, Kneese enlarged it to include regulatory agencies with their own optimal boundaries and the ability to change the terms of trade among regulated firms.

Kneese was no more Coasean than he was Pigouvian. My point is not to place him in the Coasean box instead of the Pigouvian one, but to suggest that, when we see (i) that the quintessential texts on effluent fees from the period do not even mention Pigou, (ii) that they spend more time talking about Coasean models, and yet (iii) that they relate those models to decidedly nonCoasean policy remedies, then we should begin to suspect that more is going on here than a simple Pigouvian-Coasean dichotomy. In Section 5, I will return to an alternative interpretation linking pollution pricing to American work on property rights and open access resources as well as economic development with increasing returns to scale. For now, I will limit the implications to three things that Kneese's analysis of the basin-wide firm reveals about his work.

First, Kneese thought in terms of rich and detailed political, legal, and economic institutions. Ideas like external diseconomies were not just technological relationships, they were embedded in social relationships, which required a comparative analysis of which institutions could

\footnotetext{
${ }^{19}$ As noted previously, Kneese (1964) is an early application of the Coase theorem. How this theorem came into the environmental economics literature is a matter of some speculation (Medema 2014a,b). Given Kneese's graduate training in industrial organization, and his later citation to Stigler and to an edition of Coase's paper reproduced in the 1952 Stigler-Boulding reader, Kneese was probably already familiar with "The Nature of the Firm." Coupled with the fact that Kneese (1962) discussed the idea of the basinwide firm without mentioning the negotiating result, a likely explanation is that Kneese was already thinking along these lines by working through the logic of "The Nature of the Firm" - not the "Problem of Social Cost." Medema (2020b) suggests that Jerome Milliman, who was visiting RFF around this time, may have pointed Kneese to the "Problem of Social Cost." If so, it is plausible that it fit comfortably into Kneese's existing thoughts on the subject.
} 
deliver more value. Kneese combined microeconomic theory with detailed case studies, such as his study of the Genossenschaften, the cooperative associations governing water in the Ruhr Valley, which used pollution prices among other tools (1964, Ch. 7; Kneese and Bower 1968, Ch. 13).

Second, just as he tended to institutional details, Kneese modeled the physical details of the production process, in contrast to most neoclassical models that treat production at a high level of abstraction. ${ }^{20}$ These details included attention to spatial relationships, such as the locations of economic activity and waste disposal, the delivery of services, and the effects of upstream wastes on downstream water quality. They also included how energy and materials are passed through the production process to jointly produce marketed outputs and wastes. In his seminal work on water quality, these physical relationships led him to conclude that water quality needs to be both analyzed and managed at the geographic scale of the water basin. In later work, these ideas evolved into a more general emphasis on the conservation of materials and energy (Ayres and Kneese 1969, Kneese et al. 1970). Once the balance of materials and energy were introduced as economic constraints on the joint production of material wealth and environmental quality, Kneese's logic later led him to conclude that, even if deposition was decreased in a watershed, wastes still had to go somewhere. The typical US policy approach of focusing on water quality, air quality, and solid waste separately was misguided because the flow of materials could cross over from one medium to another.

Finally, by modeling pollution through the lens of the basin-wide firm, Kneese combined external effects that Pigou would have separated into his second category (the one most similar to today's "externalities" and which Pigou illustrated by e.g. chimney smoke) and his third (economies and diseconomies among firms). While Kneese certainly understood the importance of nonrivalry and indivisibility, within the internal logic of the model of the basin-wide firm, upstream water development does not so much affect the public good of individual recreational use of water as it affects the productivity of the recreation industry. It effects the supposed downstream firm selling recreation services (tickets to a private beach). Accordingly, the model of the basin-wide firm allowed Kneese to address pollution questions using the same benefit-cost framework that

${ }^{20}$ On this point, see RFF (2001 quoting K. Smith) and Nishibayashi (2019). Nishibayashi interprets Kneese's work as following a two-step approach that begins with engineering-economic studies followed by institutional studies. 
resource economists had constructed to address questions about resource development, questions of economies of scale and scope that were inherent to large-scale water projects. These were the questions that the first generation of environmental economists had been trained to address earlier in their careers (Banzhaf 2009, 2010a, 2019). As discussed above, they were also Kneese's point of entry into work on water resources.

\section{Pollution Permits: Thomas Crocker and John Dales}

In the Pollution Pricing family tree, the first cousin to effluent charges is the tradable permit approach, now often called cap-and-trade, under which the right to pollute a fixed quantity can be traded in the market. Whereas effluent charges or pollution taxes set a price on pollution, allowing the market to determine the quantity demanded at that price, tradable permits set an upper bound on the quantity of pollution, allowing the market to determine the price at that quantity supplied. Shortly after Kneese began writing on effluent fees, two economists introduced the idea of such pollution markets, Thomas Crocker and John Dales. ${ }^{21}$ Of the two, Crocker eventually had a longer and more active career in environmental economics, yet Dales's work on pollution prices was more immediately influential, with Crocker's early contributions largely recognized in retrospect as tradable pollution permits entered mainstream policy discussions.

Thomas Crocker (b. 1937) received his $\mathrm{PhD}$ in agricultural economics from the University of Missouri in 1967, working predominantly with Mason Gaffney, whom he followed to the University of Wisconsin-Milwaukee, where he completed his dissertation and other early work on pollution pricing before eventually landing at the University of Wyoming, where he spent most of his career. (See Crocker 2011 for autobiographical details.)

John Dales (1920-2007) was a natural resource economist who spent most of his career at the University of Toronto. He received his dissertation from Harvard in 1953, working with Walter Isard, a leading economist in regional studies. ${ }^{22}$ Like other economists of the period who began to work on environmental issues, much of Dales's early work focused on water resources development, with a strong historical-institutionalist flavor. A sampler of his published titles gives a taste, starting with his dissertation, The Hydro Electric Industry in Quebec, 1898-1940 (1953) and such

\footnotetext{
${ }^{21}$ See Berta (2020b) for a recent comparison of Crocker's proposal and Dales's.

${ }^{22}$ Interestingly, this is the same year, and same advisor, as John Krutilla.
} 
other publications as "Fuel, Power, and Industrial Development in Central Canada" (1953), The Protective Tariff in Canada's Development (1966), and a comment on "Primary Products and Economic Growth" (1967).

While on a sabbatical leave in the late 1960s, Dales turned to the economics of pollution problems, publishing his thoughts in Pollution, Property and Prices (1968a), by far his best-known work. The book, which he describes as an "economico-legal" proposal for dealing with pollution (p. vi), introduces the benefit-cost logic of pollution abatement, but also limits it to a logical organizing principle. Setting benefit-cost analysis up as a strawman, Dales knocks it for having a host of measurement problems that prevent it from being a reliable empirical guide in practice (pp. 34-8, 44-50). In language that would be echoed in Demsetz's "nirvana fallacy" (1969), Dales argued that benefit-cost logic had the potential to be deceptively simple, seemingly "solving" difficult social problems when, in fact, "they were solved because we took great pains to adopt assumptions that made them solvable" (p. 36). Unlike the blackboard, realistic solutions to realworld problems, he said, required humility and recognition that ignorance is endemic to policy making (39-40).

Rather that focus on the intractable question of what is to be done, then, Dales turned to the economico-legal question of how it was to be done. His answer: Devise a system of property rights and other incentives that would let the market solve the benefit-cost problems. Even here, he said, there is no perfect solution, because private agents in the market, free riding, still will not fully reflect social values in their decisions, even as public agencies do not know the true values. Dales's proposed compromise was that a Water [or Air] Control Board set up a market by creating a certain number of pollution Rights, each giving the bearer the right to discharge one ton of wastes. $^{23}$ If the number of Rights is binding on pollution emitters, they will have scarcity value (p. 93). This approach would have the advantage, he argued, of (i) having lower administrative and policing costs than traditional regulations; (ii) of providing more certainty over the level of environmental quality than pollution charges, which would require a good deal of trial-and-error to find the price that induced the desired quality (p. 82); and (iii) of still achieving that level of environmental quality at the lowest cost possible.

\footnotetext{
${ }^{23}$ Note Dales's use of big-R "Rights," in contrast to the "tradable permits" that later developed in US policy. Dales had envisioned a stronger property right than the privileges granted by permits.
} 
Whereas Dales proposed what today would be called a system of emissions rights, Crocker proposed what today would be called ambient rights. The former lumps a group of polluters together and allows them to trade emissions 1:1, regardless of where those emissions end up, the latter lumps together all polluters who affect a specific region and allows them to trade at a ratio commensurate with their effect on that region. Each source would have to buy permits in separate markets for each region it affects, with relative prices between sources proportionate to their relative effects in each region. Thus, if Source 1 is further upwind from Region A than Source 2, it might need to buy fewer Region-A permits for each ton of its emissions than does Source 2. Similarly, he envisioned inter-temporal variation in prices (with permits earmarked to specific seasons of the year or times of day). Thus, Crocker envisioned a much more elaborate system of rights than did Dales.

As did Dales, Crocker conceded there was no perfect system, so the real question was the relative merits of a given institutional design. But tradable pollution rights, he felt, have the compelling advantage of leveraging the information-signaling power of the market price system while sidestepping "all the guesswork involved in attempting to estimate individual estimator and receptor preference functions" (1966 p. 81). He also felt they were much more practical than effluent charges or subsidies. "Although the theoretical results of varying taxes and/or subsidies and of observing actual market-determined prices may be similar," he argued,

Unless the control authority is willing to vary its taxes and subsidies over rather wide ranges for each receptor and emitter site and for each time period being considered, it will be posed with the technically impossible problem of estimating ranges of preference functions for which it has no information." (p. 82)

As Crocker (2011) recalls it, his ideas initially were developed in reaction to Kneese's proposals, and later he would take Kneese on more directly (Crocker 1968, 1972). Crocker took it for granted that achieving an ambient standard was the most important goal of pollution pricing, so he felt pollution charges were too indirect a method, requiring knowledge about the price-abatement relationship or excessive experimentation to learn it. Curiously, he did not seem to feel his own system had similar difficulties, though it required information about the transmission of pollution from each source to each receptor to set the correct trading ratios. 


\section{Pollution Trading in Context}

How shall we situate pollution trading in the context of the extant economics literature on externalities and property rights? Dales noted his intellectual debts to Coase's "Problem of Social Cost" as well as Charles Reich's "The New Property," and also to Scott Gordon's (1954) work on "The Economics of a Common-Property Resource" (pp. 110-1). He also cited Kneese (1964) as an important point of reference. For his part, Crocker was sparing in his citations in his early work, but later did discuss his proposals in relation to Kneese's and Gordon's model of the commons (1967, 1968, 1972).

What is clear from the outset is that there is absolutely no reference in either Crocker's work or Dales's to Pigou. Of course, they contrasted their ideas to Kneese's effluent charges, but Kneese's work, as I've argued, is not obviously Pigouvian either. If anything, its institutional approach bore some affinity to Coase's.

That brings us to the Coasean origins of marketable pollution rights, if any. Many standard summaries of environmental economics do draw the connection (e.g. Tietenberg 2010, Stavins 2011). On the other hand, Berta and Bertrand (2014) and Medema (2014a) have taken the opposite view, arguing that while cap-and-trade bears passing resemblance to Coase's (1959) proposal to auction bandwidth, it is closer in spirit to Arrow's (1969) model of complete competitive markets than to Coase's vision of bilateral bargaining. While Dales (1968) acknowledges "owing much" to "The Problem of Social Cost," it appears to be more for its general connection between law and economics.

As I've argued elsewhere, personally I do believe there is enough affinity between Coasean ideas and pollution trading to warrant making the association, if for no other reason than that Coase himself was proud to accept credit for the idea. ${ }^{24}$ Although Coase's vision was more about bilateral bargaining than today's liquid permit markets, in fact, in the US, actual pollution trading policies did evolve out of experience with bilateral trades, in particular EPA's "bubble" and "offset" programs. $^{25}$ More generally, pollution trading can fairly be described as Coasean insofar as it (i)

${ }^{24}$ For expansion of the points summarized here, see Banzhaf (2010b, 2020) and Banzhaf, Fitzgerald, and Schnier (2013).

${ }^{25}$ In the US, the 1970 Clean Air Act prohibited new sources of emissions in counties designated as being in "non-attainment" with ambient air quality standards, while also regulating emissions of existing sources more stringently. To lighten the costs of these regulations, in the mid-1970s the US EPA introduced an 
clarifies property rights to environmental resources like the atmosphere and introduces enforcement mechanisms for violations of those rights; (ii) reduces transactions costs by commodifying pollution, with clear units of measurement and centralized market platforms; and (iii) allows trading. Such trading becomes more Coasean in character the more salient are trades between greens and browns that endogenize the final quantity of pollution released-that is, when the "cap" in "cap-and-trade" is an upper bound on pollution and environmentalists can retire pollution rightsin contrast to fixed caps allocated only among polluters. In a Coasean worldview, such greenbrown trades are linked to the idea of reciprocal harm associated with the opportunity costs of using the atmosphere for one use versus another (e.g. deposition of wastes vs. maintenance of health, property and, today we might add, ecosystem services).

Such reciprocal costs were a linchpin in Crocker's presentation of pollution trading. Even if, he said, a marginal decrease in pollution increased net benefits, yet still,

We are no more justified in making the would-be emitter endure all the costs of "pure" air while the would-be receptor receives all the benefits than we are in burdening the receptor with all the costs of "dirty" air while the emitter collects all the benefits. (1966 pp. 62-3)

In this, Crocker disagreed with Kneese, who held up the polluter-pays principle of effluent charges as one of its virtues. Elaborating, Crocker added that

One would therefore expect the market to allocate the air's two value dimensions according to the criteria of economic efficiency. Receptors and emitters could be expected to exchange rights to the life- and property-supporting dimensions and the waste-disposal dimension until . . . the difference between total cost savings to emitters and total damage costs to receptors was maximized.

However, so far society has generally been unable to define property rights to air..." (1966 p. 65)

Such trades have signaling potential, he said, to reveal the economic value of air resources. While such green-brown trades also face free-rider problems on the green side of the market (pp. 66, 84), at least early on Crocker appeared to be sanguine about the potential to overcome such issues.

offset program to allow new sources in non-attainment areas if they could find an existing source to reduce their emissions by 1.2 tons for each ton of new emissions. Later, in 1979, the program was extended to include trades among existing sources. These programs had narrow geographic scopes, involved bilateral trades with no central market, and had to be individually approved by EPA. But it is widely believed that experience with these programs created a level of comfort with pollution trading that paved the way for later cap-and-trade programs such as the 1990 acid rain program. See Tietenberg (2006) for details. 
Dales too cracked open the door to such trades between the green and brown sides of the market. "Conservation groups," he said, "might well want to buy up some rights merely in order to prevent their being used. In this way at least part of the guerilla warfare between conservationists and polluters could be transferred into a civilized 'war with dollars"' (1968a pp. 95-6). Elsewhere, though, he minimized this possibility, characterizing his proposal as nothing more than an administrative tool. In contrast to "true" or "natural" markets, which involve "two-way communication between sources of supply and demand," he described his artificial market as providing only one-way communication, transmitting the government's decisions about the cap on pollution to the users but without the reverse feedback, so that the resulting scarcity value has no effect on the quantity of pollution supplied, nor does the value of the competing amenity use (1968b pp. 8034). "In the end," he said, "it is you and I who are going to elect the politicians who are going to decide how much pollution we are going to have" (1968a p. 104).

Before long, Crocker too had come to the same conclusion, arguing the free-rider problem would undermine green-brown trades (Crocker 1972). As pointed out by Berta (2020a), at this point, then, cap-and-trade proposals resembled the pollution charges suggested by Kneese and Baumol and Oates (1971) insofar as they were a program for efficient cost-minimization, rather than for achieving optimal pollution levels. Soon, additional work extending Dales's model would place it more in the style of work by the Cowles Commission, which highlighted the duality between Kneese's prices and Crocker and Dales's tradable quotas. Montgomery (1972), picking up on Dales's (1968b) emphasis on the artificiality of the markets, essentially crossed Dales's model with that of Arrow (1969), embedding it in an Arrow-Debreu model of competitive equilibrium. ${ }^{26}$ Weitzman (1974a) reimagined it as an application of socialist command-and-control over quantities, interpreted as dual to Lange-Lerner price controls. ${ }^{27}$ Such interpretations tend to minimize the potential for green-brown trades, emphasizing allocation among polluters of a fixed aggregate quantity.

At most, then, Coase was but one touchpoint in the intellectual network in which pollution

\footnotetext{
${ }^{26}$ See Berta (2017, 2020a) and Berta and Bertrand (2014) for discussion of this approach to modeling externalities and its relationship to cap-and-trade.

${ }^{27}$ Even here, the connection to property rights remains: Weitzman, interestingly, at the time was also working on common property and enclosure movements, albeit from a more heterodox perspective (Weitzman 1974b, Cohen and Weitzman 1975).
} 
trading operated, as it was for Kneese's proposals for effluent charges. And Pigou was hardly mentioned. As I discuss in the next section, if we are hunting for the intellectual history of pollution pricing, the recurring references to Gordon's (1954) work on common property are a more promising lead to follow.

\section{Alternative Sources for Pollution Pricing}

As influential as Pigou and Coase obviously have been, I suggest it is simply a categorical mistake to interpret the history of pollution pricing, at least as it developed in the US, through the lens of old rivalries between Cambridge and LSE. In fact, the pioneers of American environmental economics were trained in agricultural and natural resource economics or regional economics, were steeped in applied work, and had their own American literature and history of applied practices on which to draw (Banzhaf 2009, 2010, 2019).

The connection—or lack thereof—-to Pigou can perhaps best be elucidated by revisiting his three categories of situations where there is, in his view, a divergence between private and social benefits and costs. The first, recall, includes situations where productive investments might potentially be made by people who do not own the instrument of production being maintained or enhanced, such as tenant farmers. The second involves situations where one person, when rendering some compensated service to another, incidentally also renders services or disservices to third parties. The third comprises situations where there are increasing or decreasing returns at the industry level. Though with antecedents in Mill and Sidgwick, Pigou's second grouping is the one most original to and uniquely associated with him. Additionally, it is the one closest to today's concept of "externalities," and which had gone dormant in the literature from the 1930s to late '50s.

But if we are trying to understand the historical context of pollution pricing circa 1965, I suggest it is the first and third groupings—not the second — that are most relevant. Being less unique to Pigou, these issues are then more likely have been associated with other, non-Pigouvian traditions.

Economies of Scale and Scope

Let's consider first the notion of external economies (or diseconomies) from one firm to another within the industry, or from one industry to another, with expansion by one firm changing the supply price of other firms (Pigou's third grouping). These kinds of effects were historically 
important for environmental economics because its intellectual roots lie as much in the study of natural resources as public goods and externalities. And, at least in the US, studying natural resources meant studying their development. Development of resources was, arguably, engrained in the American worldview well into the mid $20^{\text {th }}$ Century. In his Frontier Thesis (1893), Frederick Jackson Turner had famously argued that America's civic and social development were dependent on its resource development: As Americans moved west, taming the frontier made them ever more self-reliant, while as settlements grew in its wake they became more civilized as well. Here is a story of external economies writ large: The development of resources spilled over to all civilizing and democratizing forces. Whatever the merits of Turner's thesis, it was quite influential. Consequently, the closing of the frontier in the late $19^{\text {th }}$ century prompted renewed efforts to develop existing resources.

In the American west, developing water resources was a paramount concern. West of the $100^{\text {th }}$ meridian, farming requires irrigation, but even early irrigation ditches required cooperative construction and management, as a ditch scaled to serve only a single farm would lose all its water to evaporation (Teele 1904, 1926, Coman 1911). Thus, economies of scale at the industry level were present. As recently argued by Leonard and Libecap (2019), the evolution of water rights in the American West from riparian rights to prior appropriation was one organic response to this problem. Later, larger-scale development of ever larger regions, further from water sources, seemingly justified federal support for massive water projects.

This push for development might appear to conflict with the growing conservation movement led by Gifford Pinchot (1865-1946) and others, but the conservation movement, perhaps ironically, emphasized developing resources as much as conserving them. ${ }^{28}$ From Pinchot's perspective, development and conservation were two prongs in the progressive attack on waste. As he wrote in The Fight for Conservation (1910):

The first principle of conservation is development, the use of the natural resources now existing on this continent for the benefit of the people who live here now. There may be just as much waste in neglecting the development and use of certain natural resources as there is in their destruction. ....

Conservation stands emphatically for the development and use of water-power

\footnotetext{
${ }^{28}$ See Hays (1959). Banzhaf (2019) discusses the importance of this aspect of the conservation movement in the history of environmental economic thought.
} 
now, without delay. It stands for the immediate construction of navigable waterways under a broad and comprehensive plan as assistants to the railroads. More coal and more iron are required to move a ton of freight by rail than by water, three to one. In every case and in every direction the conservation movement has development for its first principle, and at the very beginning of its work. The development of our natural resources and the fullest use of them for the present generation is the first duty of this generation. ....

In the second place conservation stands for the prevention of waste. There has come gradually in this country an understanding that waste is not a good thing and that the attack on waste is an industrial necessity. I recall very well indeed how, in the early days of forest fires, they were considered simply and solely as acts of God, against which any opposition was hopeless and any attempt to control them not merely hopeless but childish. It was assumed that they came in the natural order of things, as inevitably as the seasons or the rising and setting of the sun. Today we understand that forest fires are wholly within the control of men. So we are coming in like manner to understand that the prevention of waste in all other directions is a simple matter of good business. The first duty of the human race is to control the earth it lives upon. (1910 pp. 43-5)

Thus, Pigou was only half right when he stated that "the whole movement for 'conservation' in the United States is based on" the conviction that "the State should protect the interests of the future in some degree against the effects of our irrational discounting and of our preference for ourselves over our descendants" (1932 p. 29). The other half of the story is that the state should develop resources immediately so they are not "wasted" by remaining unused.

Such thinking was quite influential. At a famous Governors' conference on conservation organized by Pinchot, President Theodore Roosevelt remarked in his opening address that:

Every step of the progress of mankind is marked by the discovery and use of natural resources previously unused. Without such progressive knowledge and utilization of natural resources population could not grow, nor industries multiply, nor the hidden wealth of the earth be developed for the benefit of mankind.

Interestingly, here natural resources are conceived of not just as a material input, but inextricably linked to technological progress - to "discovery" and "progressive knowledge." In other words, what anachronistically we might call both productivity and resource deepening.

Naturally, the academic literature was concerned with such issues as well. Pigou treated them in his third grouping, but as noted previously they were refined and developed by Young (1913, 1928), Knight (1924), Viner (1932), Ellis and Fellner (1943), and Meade (1952). For the most part, this literature addressed issues of external (dis)economies in the context of trade and/or 
development. ${ }^{29}$ Allyn Young, a student of Richard Ely, initially developed his critique of Pigou's theory by distinguishing real costs from the price effects of changing land rent (Young 1913), an argument taken up by Knight as well. Later, he analyzed economies of scale through the lens of Adam Smith's statement that expanding the extent of the market could facilitate the division of labour (Young 1928). But such forces depended on natural resources. Natural scarcities in the supply of resources and indivisibilities in production created barriers to such scale economies, he said, while the discovery of new natural resources and the growth of scientific knowledge reinforced them. "[O]ut of better knowledge of the materials and forces upon which men can lay their hands there come both new ways of producing familiar commodities and new products" (p. 535).

The spatial scale of such gains from specialization also were an important consideration. As Ellis and Fellner (1943) emphasized,

Certain industries must usually reach some stage of growth before a geographical region starts to develop significantly and also before human and material resources become more specialized. But it is rarely true in these cases that a contraction of the output of any one industry would lead to a loss of the economies in question. (p. 507)

In their thinking, these irreversible external economies prevented competitive markets from allocating resources optimally and justified inducements.

In the middle of the century, these concerns about resource development began to occupy the interest of the economists who would shape environmental economics in the coming decades. Consider just the titles of three key works in benefit-cost analysis published in 1958 alone:

- Multiple Purpose River Development, by John V. Krutilla and Otto Eckstein;

- Water Resources Development: The Economics of Project Evaluation, by Otto Eckstein; and

- Efficiency in Government through Systems Analysis with Emphasis on Water Resource Development, by Roland McKean.

As mentioned previously, Kneese published "Normative Problems in the Evaluation of Water-

\footnotetext{
${ }^{29}$ Currie (1997), Boianovsky and Hoover (2009) and Alacevich (2020) discuss Young's place in neoclassical models of growth and development. McDonald (2013) discusses Knight's debate with Pigou. Medema (2020a) discusses how Meade's distinction between "unpaid factors of production," including his famous discussion of bees and orchards, and "atmosphere" effects were worked out in the context of trade and development.
} 
Resources Development Projects" (1960) around the same time. Thus, before they were calling attention to the deleterious effects of development on environmental amenities, Kneese and Krutilla were focused more on the beneficial spillovers of development, mentioning environmental externalities only in passing. Instead, they identified the crucial issue creating departures from competitive conditions as large external economies from indivisibilities and jointness in production technologies and from interdependence of the production functions of independent producers (Krutilla and Eckstein 1958 pp. 42-77). Jointness meant that most water projects were multipurpose, so could be thought of as direct inputs into several industries simultaneously, with no one industry (let alone firm) having the full incentive to invest in them. Interdependences implied further indirect effects from one firm to another. For example, both Krutilla and Eckstein (1958 pp. 56-7) and Kneese (1960 pp. 311-12) mention the possibility that irrigating some farms from surface water would recharge the aquifers used by other farmers. Similarly, upstream storage presents external economies to downstream hydroelectric power. At a larger scale, development of sparsely populated areas can enhance productivity by increasing the extent of the market and so extending the division of labor. ${ }^{30}$

Even when their focus turned from natural resource scarcity to scarcity of environmental amenities, this pattern of thought continued to guide economists' thinking. For example, as discussed above, Kneese often thought in terms of the joint effects of firms and industries on pollution levels within a collectively shared water resource, which in turn affects downstream industries like recreation (Kneese 1964, Kneese and Bower 1968), an extension of inter-industry external economies that fit Coase's ideas as well as Pigou's. Earlier, questions about how to measure the monetary value of such outdoor recreation-arguably the first exercises in pricing the environment-first arose from thinking about ancillary benefits of building reservoirs in order to justify more development projects (Banzhaf 2010, 2018). Finally, Davidson et al. (1966) introduced the possibility of external economies from learning-by-doing in outdoor recreation, as investments in environmental amenities induced participation that would then beget more participation, increasing the value of the initial investment. Thus, in these ways, early work in environmental economics often

\footnotetext{
${ }^{30}$ As discussed in Porter (1995) and Banzhaf (2009), quantifying such secondary benefits was hotly contested in applied benefit cost analysis. The Federal Inter-Agency River Basin Committee's so-called "green book" (1950) downplayed their importance.
} 
was framed in terms of increasing returns to scale.

\section{Property Rights and Land Tenancy}

Equally important are the issues that might be placed into Pigou's first grouping, land tenancy. Here especially, American economists had their own traditions to draw on. To see this, one need look no further than Pigou's own text, where at points he relies on Henry Taylor's discussion of certain contractual arrangements that can help overcome land tenancy problems (Taylor 1919). Taylor, another student of Richard Ely's, was one of the central figures in the creation of American agricultural economics (see Banzhaf 2006).

This grouping is as close as Pigou came in the Economics of Welfare to discussing property rights arrangements for the use of natural resources. Whereas in the other two groupings he thought in terms of the effects of particular actions, here Pigou thought in terms of investment in or depreciation of a natural resource (land) being used by multiple agents (the tenant now, but eventually the owner when it reverts back to him or another tenant who takes up the lease). Thus, though Pigou primarily discussed the incentives of a tenant farmer, the logic applies to other situations where individual have an incentive to deplete a resource held in common.

That common property resources are germane to environmental problems is almost too obvious to spell out, but four historical touchstones underscore their importance as an ongoing theme in North American conservation and environmental thought. All four also highlight the recurring use of analogical reasoning from agricultural land tenancy to commonly held natural resources and back.

Perhaps most famously, in 1968, near the peak of the environmental movement, Garrett Hardin's "Tragedy of the Commons" invited readers to "picture a pasture open to all. It is to be expected that each herdsman will try to keep as many cattle as possible on the commons" (p. 1244). The result is ruin for each herdsman, as overgrazing destroys the grass. In the same way, Hardin said, the earth and its ecosystem are a common resource supporting all humanity, a commons being depleted. Whatever the merits of Hardin's arguments, it struck a popular chord, with discussions of common property ballooning in the environmental literature soon after.

Second, over a decade earlier, Scott Gordon (1954) and Anthony Scott (1955) also had 
drawn attention to common property problems. Both recognized the wisdom in the popular aphorism that "everybody's property is nobody's property," but demonstrated formally how under open access competition would deplete the value of resources. Though their focus was on overfishing, they too made the connection to common tenure in land. Gordon in particular offered a discursive discussion of hunting and trapping as well as agriculture, and the endogenous formation of alternative forms of property rights when resources become scarcer (pp. 134-5).

Third, at the turn of the $20^{\text {th }}$ Century, Richard Ely, the godfather of American agricultural economics, relied extensively on analogies between capital, agricultural land, and natural resources. ${ }^{31}$ The possibility of investing in a soil's fertility or depleting it, he said, makes land similar to man-made capital. Likewise, both resemble natural resources. Indeed, in the first edition of Outlines of Economics (1893), Ely suggested classifying the factors of production into three categories: nature (rather than land), labor, and capital. Nature includes all natural forces, but in economics it is often called land, he said, because that is a prominent aspect that is priced and exchanged. Land, viewed this way, includes "standing space" (i.e. pure extension), soil fertility, and subsurface minerals (1893 pp. 99-100). Over the course of revising various editions of his books, Ely steadily expanded on these themes. By 1940, Ely and Wehrwein organized their definitive text Land Economics first around chapters related to land as nature and standing space respectively, then, after a discussion of property rights, around various uses of land, such as agriculture, forestry, "the environment and recreational land," water resources, mineral resources, and cities.

In Ely's writing and others' in the period, the analogies between land and other resources ran both ways. Just as we can understand many natural resource problems by analogy to agricultural economics, so too can we understand some questions in agricultural economics by reasoning analogically to depletable natural resources. In particular, the soil is a resource, with an optimal path of depletion (and/or renewal). This theme is well represented in the work of Lewis Gray, a student of Ely and Taylor at Wisconsin, who made important contributions to the economics of exhaustible resources (e.g. Gray 1913). ${ }^{32}$ Gray's treatment of natural resources moved back and

\footnotetext{
${ }^{31}$ See Bateman and Kapstein (1999) and Kaufman (2017) for background on Ely and his role in the history of economic thought.

${ }^{32}$ For biographic background on Gray and appraisals of his work and its relationship to Hotelling's later more famous contributions, see Kirkendall (1963), Crabbé (1983), and Missemer et al. (2019).
} 
forth between the example of farmland and the example of coal. Whereas the latter is necessarily depleted through utilization, the former is physically depletable but potentially renewable through cover crops and manuring. Whether farmland is actually exhausted depends in part on custom and habit, which can prolong wasteful practices long after they are in a farmer's self-interest, but also on economic conditions including the rate of interest and the cost of replenishment.

Picking up on these themes, Ely and Wehrwein wrote that

Indestructible' agricultural land is a myth, and the reason why it has been depleted and destroyed is that it must have paid the farmer to do so. It is useless to argue that it should pay to maintain or build up soil fertility unless the operator has a longtime interest in the soil. Soil has an exhaustion value similar to a forest or a mine. The American farmer has often found it more profitable to exhaust the virgin fertility of one farm and move to a new farm than to try to maintain or restore the fertility on his old one. The farmer who claimed he was a good farmer because he had worn out four farms already was not far from the truth if judged by narrow "economic" standards. (1940 p. 216; see also pp. 390-91)

Like Gray, Ely and Wehrwein didn't necessarily approve of such outcomes. But they pointed the blame at the incentives created by existing property rights arrangements, including, among other things, the homestead law and the tenure system, by which those tenants who were "climbers" depleted land in an effort to raise cash to buy their own farm, then later turned their farm over to tenants to retire to the city, or California (pp. 216-7). ${ }^{33}$

Finally, illustrating the popular character of such analogies, President Theodore Roosevelt at the 1908 Governors' conference drew a parallel between the nation's stewardship of natural resources and a farmer's stewardship of the land. The problem of excessive depletion of resources, he said, could be understood by analogy to a farmer's stewardship of the soil. "Every one knows that a really good farmer leaves his farm more valuable at the end of his life than it was when he first took hold of it. So with the waterways. So with the forests." But stewardship of the land is grounded in the incentives of property rights. "We should exercise foresight now," he said,

\footnotetext{
${ }^{33}$ Similar problems, of course, arise in forestry. Ely and Wehrwein approach this topic by first considering "the forest as a mine," before turning to questions of conservation and reforestation (1940 Ch. 9). As developed over the course of the $20^{\text {th }}$ Century, the parallels between forestry and capital became even stronger than those between farmland and capital. For example, as noted by Bowes and Krutilla (1985), optimal rotations for a forest that yields environmental "services" while it grows and timber value when harvested look, mathematically, exactly like the optimal life cycle for a machine that yields a flow of output and has scrappage value. (See also Gaffney 1957 and Hirshleifer 1970.)
} 
as the ordinarily prudent man exercises foresight in conserving and wisely using the property which contains the assurance of well-being for himself and his children. We want to see a man own his farm rather than rent it, because we want to see it an object to him to transfer it in better order to his children. We want to see him exercise forethought for the next generation. We need to exercise it in some fashion ourselves as a nation for the next generation.

In this way, care of resources can be understood by analogy to questions of land tenure.

Situated in the middle of these policy discussions, and as heirs of this tradition in agricultural and resource economics, it would be natural for American economists in the 1960s to think along similar lines. Kneese, recall, also employed his own analogy between agriculture and the natural environment, segueing from a discussion of the farm with Plots A and B to the basin-wide water firm. Certainly, like Pigou, he considered situations where an exchange between two parties affects a third party. But, reasoning with categories of natural resources which have alternative uses, Kneese considered how such affects are mediated through misaligned incentives to allow a resource to depreciate: "Failure of municipal and industrial waste dischargers to consider that subsequent water uses may be made more expensive or foreclosed entirely by the discharge is perhaps the basic element of the pollution problem" (1964 p. 42, emphasis in original). In other words, polluters depreciate a resource that has alternative uses downstream, such as fishing. Downstream users of the water, here, subsequent in time and space to the upstream user, play the role of subsequent users of farmland after the tenant.

By the close of the decade, Kneese was explicitly trying to situate his work in the context of common property resources. He claimed that, while it is natural for economists to begin thinking about environmental problems through the lens of "externalities," the new approach stemming from Economics of Regional Water Quality Management could better be described as "the management of common property resources approach" (1971b p. 153, emphasis in original). Kneese characterized the externalities approach as inherently limited to two-party situations, whereas the common property approach focuses on the degradation of a resource used by many. Concomitantly, whereas externalities have the appearance of being rare exceptions to the competitive ideal, the logic of materials balancing compels us to recognize that depositing wastes in the environment is a pervasive aspect of production (1971b, Ayres and Kneese 1969). Accordingly, drawing on Gordon (1954), he argued that, now that the natural environment is itself a scarce resource, "we are confronted with a vast asymmetry in the ability of our property institutions to form the basis 
for efficient resources allocation" (1971b p. 155).

Explaining his proposals for effluent charges to the US Congress, Kneese (1969) framed it in similar terms. "I think we must devise ways of reflecting the costs of using resources that are the common property of everyone, like our watercourses," he said. "Because our property institutions cannot adequately be applied to resources like watercourses, and for that matter the air and space, they are in fact unpriced and treated as free goods, even though they are in fact resources of great and increasing value in the contemporary world. ...[T]his unfortunate situation cannot be remedied unless we move toward the implementation of publicly administered prices for waste discharge to watercourses and for the use of other common property resources" (p. 347).

Like Kneese, Crocker and Dales also reasoned from these mis-aligned incentives of common property, with Gordon (1954) being one of the few references provided by either (Crocker 1967, 1968, Dales 1968a,b). Dales emphasized that, because air and water are fluids that fail to respect boundaries, it seems inevitable that they will be held in common. Crocker made a similar point, adding that whereas with land and most other resources, man can modify its characteristics to mitigate consequences of misaligned incentives (e.g. by regrading a slope to prevent a tenant from eroding the soil), but with air we are subject to its whims (1966 p. 63).

Crocker additionally stressed the distinction between "air" and "air space," the former referring to the gasses that move about in space and time, and the latter the space through which they move. This distinction is interesting because it echoes the one Richard Ely made between "land" and "standing space." As discussed above, by the latter Ely meant pure Cartesian extension to be occupied by people and economic activity, whereas in the former he included all the quality-differentiated resources of the land (Ely 1893 pp. 99-100), Ely and Morehouse 1924 Ch. 2). Extending this logic, Ely said that, like land, water too can be distinguished between the space it occupies and the resource itself (Ely and Morehouse 1924 Ch. 9, Ely and Wehrwein 1940 Ch. 11). Because underground water flows throughout a basin, a single user can deplete the reservoir, denying others use, particularly problematic in the arid west. Thus, California for example developed the doctrine of "correlative right," which limits users to a reasonable share (see also Comin 1911, CiriacyWantrup 1956).

Earlier in his graduate career, Crocker had been assisting his advisor on just this issue (Gaffney 1961 p. 30), and he recalls it being an important inspiration for his work on rights to the 
air (Crocker 2011). Highlighting this connection, Crocker wrote that the current treatment of property rights to air obviously resembles "the problems caused by the old absolute-ownership doctrine of groundwater" (1967 p. 36). This old doctrine of absolute ownership, Crocker explained, "defines the groundwater user's rights in terms of reservoir space, but fails to define his rights relative to the rights of other groundwater users in the water that percolates through that space." Even if users had a de jure right, they would have no economical means by which to defend them (1967 p. 36). For air as with groundwater, "the result is that the owner of the space uses the resource within the space until such time as for him and him alone the present value of its marginal value product is zero" (1966 pp. 82-3).

Crocker and Dales both suggested that, although historically it was appropriate to treat air or water as a "free good," the demands on their use were now too high to do so. Crocker summed up the problem with the commons by mashing together quotes from Ellis and Fellner (1943), Gordon (1954) and Bator (1968), stating that the "'divorce of scarcity from effective ownership' brings about a situation in which 'the conservative dictum that everybody's property is nobody's property' appears to be fulfilled" (1968 pp. 247-8).

\section{Conclusion}

This paper has argued that the early literature on pollution pricing was rooted in questions about common property resources and the increasing returns from developing natural resources. Both topics were treated by broad literatures by the 1960s, including distinctly American traditions not particularly associated with Pigou. On this reading, if the Pigouvian framework was later grafted onto the rootstock of an already flourishing school of environmental economics, those roots were already well grounded in an American tradition of applied agricultural economics and natural resource economics.

This history has broader implications for our understanding of externalities and public goods. In the 1950s and '60s, the definition of public goods was crystallizing around the idea that they simultaneously involve non-excludability and either jointness in production or nonrivalry in consumption (Desmarais-Tremblay 2017). Throughout that process, Samuelson, Musgrave, and others debated the relative importance of free riding and jointness, and how to overlay the theory of externalities. At the same time, Buchanan, Tiebout and others offered alternative perspectives 
with the potential for voluntary mechanisms to overcome these problems. ${ }^{34}$ Arguably, these are the same issues that simultaneously were playing out in the history of applied environmental and natural resource economics. Challenges in the management of natural resources had long been understood to be related to jointness in appropriation (e.g. irrigation and dams) and the incentives under common property arrangements. Even as concerns about the quantity of material resources gave way in the 1960s to greater emphasis on the quality of environmental amenities, these traditional perspectives remained. The water and air are common property resources which support environmental services that are nonrivalrous among those who enjoy them, but which jointly are rivalrous against alternative uses of the resources for the deposition of wastes. Economists like Kneese, Crocker, and Dales proposed market-like systems to close off access to such common property resources. Once operating, these systems could operate in a decentralized way, but establishing them still required managing prices, quotas, the terms of trade, and the extent of the market.

${ }^{34}$ On both these issues, see e.g. Berta (2017), Desmarais-Tremblay (2017), Fontaine (2014), Johnson (2015), Marciano (2013), and Singleton (2015). 


\section{References}

Alacevich, Michele. 2020. "Paul Rosenstein-Rodan and the Birth of Development Economics." CHOPE Working Paper 2020-04.

Arrow, Kenneth J. 1969. "The Organization of Economic Activity: Issues Pertinent to the Choice of Market versus Non-Market Allocation." In The Analysis and Evaluation of Public Expenditures: The PPB System, pp. 47-64. US Congress, Joint Economic Committee. Washington, DC: US Government Printing Office.

Aslanbeigui, Nahid, and Guy Oakes. 2015. Arthur Cecil Pigou. London: Palgrave Macmillan.

Ayres, Robert U., and Allen V. Kneese. 1969. "Production, Consumption, and Externalities." American Economic Review 59(3): 282-97.

Backhouse, Roger E., and Steve G. Medema. 2009a. "Defining Economics: The Long Road to Acceptance of the Robbins Definition." Economica 76: 805-20.

Backhouse, Roger E., and Steven G. Medema. 2009b. "Retrospectives: On the Definition of Economics." Journal of Economic Perspectives 23(1): 221-33.

Banzhaf, H. Spencer. 2006. "The Other Economics Department: Demand and Value Theory in Early Agricultural Economics." In Agreement on Demand: The History of $20^{\text {th }}$ Century Demand Theory, ed. by P. Mirowski and W. Hands. Durham, NC: Duke University Press, pp. 9-31.

Banzhaf, H. Spencer. 2009. "Objective or Multi-Objective? Two Historically Competing Visions for Benefit-Cost Analysis." Land Economics 85(1): 3-23.

Banzhaf, H. Spencer. 2010a. "Consumer Surplus with Apology: A Historical Perspective on Nonmarket Valuation and Recreation Demand." Annual Review of Resource Economics 2(1): 183-207.

Banzhaf, H. Spencer. 2010b. "The Free Market Environmentalist Case for Cap and Trade." Working Paper, Property and Environmental Research Center.

Banzhaf, H. Spencer. 2017. "Constructing Markets: Environmental Economics and the Contingent Valuation Controversy." In The Age of the Applied Economist: The Transformation of Economics Since the 1970s, ed. by Roger E. Backhouse and Beatrice Cherrier. Durham, NC: Duke University Press, pp. 213-39.

Banzhaf, H. Spencer. 2019. "The Environmental Turn in Natural Resource Economics: John Krutilla and 'Conservation Reconsidered."' Journal of the History of Economic Thought 41(1): 27-46.

Banzhaf, H. Spencer. 2020. "The Conservative Roots of Carbon Pricing." National Affairs, forthcoming. 
Banzhaf, H. Spencer, Timothy Fitzgerald, and Kurt Schnier. 2013. "Nonregulatory Approaches to the Environment: Coasean and Pigouvian Perspectives." Review of Environmental Economics and Policy 7(2): 238-58.

Bateman, Bradley W., and Ethan B. Kapstein. 1999. "Retrospectives: Between God and the Market: The Religious Roots of the American Economic Association. Journal of Economic Perspectives 13(4): 249-58.

Bator, Francis M. 1957. "The Simple Analytics of Welfare Maximization." American Economic Review 47(1): 22-59.

Bator, Francis M. 1958. "The Anatomy of Market Failure." Quarterly Journal of Economics 71(3): 351-79.

Baumol, William J. 1952. Welfare Economics and the Theory of the State. London: Longmans, Green, and Co.

Baumol, William J., and Wallace E. Oates. 1975. The Theory of Environmental Policy. Englewood Cliffs, New Jersey: Prentice-Hall.

Berta, Nathalie. 2017. "On the Definition of Externality as a Missing Market." European Journal of the History of Economic Thought 24(2): 287-318.

Berta, Nathalie. 2019. "The History of Incentives in Environmental Economics." In Incentives and Environmental Policies: From Theory to Empirical Novelties, ed. by Benjamin Ouvrard and Anne Stenger, pp. 31-54. London: ISTE.

Berta, Nathalie. 2020a. "Efficiency without Optimality: A Pragmatic Compromise for Environmental Policies in the Late 1960s." Journal of the History of Economic Thought, forthcoming.

Berta, Nathalie. 2020b. "A Note on the Early History of Emission Trading and Cap-and-Trade in the Late 1960s." Cahiers d'économie politique, forthcoming.

Berta, Nathalie, and Elodie Bertrand. 2014. "Market Internalization of Externalities: What is Failing?" Journal of the History of Economic Thought 36(3): 331-57.

Bertrand, Elodie. 2015. "From Firm to Economic Policy: The Problem of Coase's Cost." History of Political Economy 47(3): 481-510.

Boianovsky, Mauro, and Kevin D. Hoover. 2009. "The Neoclassical Growth Model and Twentieth-Century Economics." In Robert Solow and the Development of Growth Economics, ed. by Mauro Boianovsky and Kevin D. Hoover. Durham: Duke University Press, pp. 123.

Bowes, Michael D., and John V. Krutilla. 1985. "Multiple Use Management of Public Forestlands." In Handbook of Natural Resource and Energy Economics, vol. 2, ed. by Allen V. Kneese and James L. Sweeney. Amsterdam: North Holland. 
Buchanan, James M., and Wm. Craig Stubblebine. 1962. "Externality." Economica 29: 371-84.

Ciriacy-Wantrup, S.V. 1956. "Concepts used as Economic Criteria for a System of Water Rights." Land Economics 32(4): 295-312.

Coase, R.H. 1937. "The Nature of the Firm." Economica 4: 386-405.

Coase, R.H. 1959. "The Federal Communications Commission." Journal of Law and Economics 2:1-40.

Coase, R.H. 1960. "The Problem of Social Cost." Journal of Law and Economics 3: 1-44.

Cohen, Jon S., and Martin L. Weitzman. 1975. "A Marxian Model of Enclosures." Journal of Development Economics 1(4): 287-336.

Collard, David. 1996. "Pigou and Future Generations: A Cambridge Tradition." Cambridge Journal of Economics 20(5): 585-97.

Coman, Katharine. 1911. "Some Unsettled Problems of Irrigation." American Economic Review 1(1): 1-19.

Crabbé, Philippe J. 1983. "The Contribution of L.C. Gray to the Economic Theory of Exhaustible Natural Resources and its Roots in the History of Economic Thought." Journal of Environmental Economics and Management 10: 195-220.

Crocker, Thomas D. 1966. "The Structuring of Atmospheric Pollution Control Systems." In The Economics of Air Pollution, ed. by Harold Wolozin, pp. 61-86. New York: W.W. Norton \& Co.

Crocker, Thomas D. 1967. Some Economics of Air Pollution Control. Dissertation, University of Missouri.

Crocker, Thomas D. 1968. "Some Economics of Air Pollution Control." Natural Resources Journal 8(2): 236-58.

Crocker, Thomas D. 1972. "On Air Pollution Control Instruments," Loyola of Los Angeles Law Review 5: 280-97.

Crocker, Thomas D. 2011. "Trading Access to and Use of the Natural Environment: The Multiple Origins of 'Cap and Trade."' Working paper, University of Wyoming.

Currie, Lauchlin. 1997. "Implications of an Endogenous Theory of Growth in Allyn Young's Macroeconomic Concept of Increasing Returns," ed. by Roger Sandilands. History of Political Economy 29(3): 413-43.

Dales, J.H. 1968a. Pollution, Property, and Prices. University of Toronto Press.

Dales, J.H. 1968b. "Land, Water, and Ownership." Canadian Journal of Economics 1(4): 791804. 
Davidson, Paul, F. Gerard Adams, and Joseph Seneca. 1966. "The Social Value of Water Recreational Facilities Resulting from an Improvement in Water Quality: The Delaware Estuary." In Water Research, ed. by Allen V. Kneese. Baltimore: The Johns Hopkins Press for Resources for the Future.

Davis, Robert K. 1968. The Range of Choice in Water Management: A Study of Dissolved Oxygen in the Potomac Estuary. Baltimore: The Johns Hopkins Press for Resources for the Future.

Davis, Otto A., and Andrew Whinston. 1962. "Externalities, Welfare, and the Theory of Games." Journal of Political Economy 70(3): 241-62.

Desmarais-Tremblay, Maxime. 2017. "Musgrave, Samuelson, and the Crystallization of the Standard Rationale for Public Goods." History of Political Economy 49(1): 59-92.

Eckstein Otto. 1958. Water-Resource Development: The Economics of Project Evaluation. Cambridge, MA: Harvard University Press.

Ellis, Howard S., and William Fellner. 1943. "External Economies and Diseconomies." American Economic Review 33(3): 493-511.

Ely, Richard T. 1893. Outlines of Economics. New York: Meadville Penna.

Ely, Richard T. 1911. Outlines of Economics, $2^{\text {nd }}$ ed. With Thomas S. Adams, Max O. Lorenz, and Allyn A. Young. New York: Macmillan.

Ely, Richard T., and Edward W. Morehouse. 1924. Elements of Land Economics. New York: Macmillan.

Ely, Richard T., and George S. Wehrwein. 1940. Land Economics. New York: Macmillan.

Fontaine, Philippe. 2014. "Free Riding." Journal of the History of Economic Thought 36(3): 35976.

Fort, D.M., W.A. Niskanen, A.H. Pascal, W.F. Sharpe. 1959. "Proposal for a 'Smog Tax."' RAND Corporation paper P-1621-RC.

Freeman, A. Myrick III, and Robert H. Haveman. 1972. "Residuals Changes for Pollution Control: A Policy Evaluation." Science 177: 322-9.

Gaffney, Mason. 1957. "Concepts of Financial Maturity of Timber and Other Assets." Agricultural Economics Information Series paper no. 62, Raleigh, NC.

Gaffney, Mason. 1961. "Diseconomies Inherent in Western Water Laws: A California Case Study." In Water and Range Resources and Economic Development of the West, Proceedings of the Western Agricultural Resource Council. www.masongaffney.org/publications/H3-DiseconomiesInherentinWesternWaterLaws21.CV.CV.pdf 
Gordon, H. Scott. 1954. "The Economic Theory of a Common-Property Resource: The Fishery." Journal of Political Economy 62(2): 124-42.

Gray, L.C. 1913. "The Economic Possibilities of Conservation." Quarterly Journal of Economics 27(3): 497-519.

Hardin, Garrett. 1968. "The Tragedy of the Commons." Science 162: 1243-48.

Hays, Samuel P. 1959. Conservation and the Gospel of Efficiency: The Progressive Conservation Movement, 1890-1920. Cambridge: Harvard University Press.

Hays, Samuel P. 1982. "From Conservation to Environment: Environmental Politics in the United States since World War Two." Environmental Review 6: 14-41.

Hays, Samuel P. 1987. Beauty, Health, and Permanence: Environmental Politics in the United States, 1955-1985. Cambridge: Cambridge University Press.

Hirshleifer, Jack. 1970. Investment, Interest and Capital. Englewood Cliffs, NJ: Prentice-Hall.

Hirshleifer, Jack, James Charles De Haven, and Jerome W. Milliman. 1960. Water Supply: Economics, Technology, and Policy. Chicago: The University of Chicago Press.

Inter-Agency Committee on Water Resources, Subcommittee on Evaluation Standards. 1960. Report of the Panel of Recreational Values on a Proposed Interim Schedule of Values for Recreational Aspects of Fish and Wildlife.

Johnson, Edwin L. 1967. "A Study in the Economics of Water Quality Management." Water Resources Research 3(2): 291-305.

Johnson, Marianne. 2015. "Public Goods, Market Failure, and Voluntary Exchange." In Market Failure in Context, ed. by Alain Marciano and Steven G. Medema. Durham, NC: Duke University Press, pp. 174-98.

Kaufman, Bruce E. 2017. "The Origins and Theoretical Foundation of Original Institutional Economics Reconsidered." Journal of the History of Economic Thought 39(3): 293-322.

Kirkendall, Richard S. 1963. "L.C. Gray and the Supply of Agricultural Land." Agricultural History 37(4): 206-14.

Kneese, Allen V. 1956. An Industry Study Approach to the Problem of Exclusive Dealing. Dissertation, Indiana University.

Kneese, Allen V. 1960. "Normative Problems in the Evaluation of Water-Resources Development Projects." Southwestern Social Sciences Quarterly 40(4): 301-13.

Kneese, Allen V. 1962. Water Pollution—Economic Aspects and Research Needs. Washington, DC: Resources for the Future. 
Kneese, Allen V. 1964. The Economics of Regional Water Quality Management. Baltimore: Johns Hopkins Press for Resources for the Future.

Kneese, Allen V. 1969. "Statement of Allen V. Kneese, Director, The Quality of the Environment Program for Resources for the Future, Inc." In Economic Analysis and the Efficiency of Government: Hearings before the Subcommittee on Efficiency of Government of the Joint Economic Committee, $91^{\text {st }}$ Cong., pp. 342-9.

Kneese, Allen V. 1971a. "Background for the Economic Analysis of Environmental Pollution." Swedish Journal of Economics 73(1): 1-24.

Kneese, Allen V. 1971b. "Environmental Pollution: Economics and Policy." American Economic Review 61(2): 153-66.

Kneese, Allen V. 1988. "Three Decades of Water Resources Research: A Personal Perspective." In Environmental Resources and Applied Welfare Economics: Essays in Honor of John V. Krutilla, ed. by V. Kerry Smith. Washington, DC: Resources for the Future.

Kneese, Allen V., Robert U. Ayres, and Ralph C. d'Arge. 1970. Economics and the Environment: A Materials Balance Approach. Johnsons Hopkins University Press for Resources for the Future.

Kneese, Allen V., and Blair T. Bower. 1968. Managing Water Quality: Economics, Technology, Institutions. Baltimore: Johns Hopkins Press for Resources for the Future.

Kneese, Allen V., and Karl-Göran Mäler. 1973. "Bribes and Charges in Pollution Control: An Aspect of the Coase Controversy." Natural Resources Journal 13: 705-15.

Kneese, Allen V., and Kenneth C. Nobe. 1962. "The Role of Economic Evaluation in Planning for Water Resource Development." Natural Resources Journal 2: 445-82.

Kneese, Allen V., and Charles L. Schultze. 1975. Pollution, Prices, and Public Policy. Washington, DC: The Brookings Institution.

Knight, F.H. 1924. "Some Fallacies in the Interpretation of Social Cost." Quarterly Journal of Economics 38(4): 582-606.

Krutilla, John V. 1967. "Conservation Reconsidered." American Economic Review 57(4): 77786.

Krutilla, John V. 1981. "Reflections of an Applied Welfare Economist." Journal of Environmental Economics and Management 8: 1-10.

Krutilla, John V., and Otto Eckstein. 1958. Multiple Purpose River Development: Studies in Applied Economic Analysis. Baltimore: Johns Hopkins University Press for Resources for the Future.

Kula, E. 1998. History of Environmental Economic Thought. London: Routledge. 
Kumekawa, Ian. 2017. The First Serious Optimist: A.C. Pigou and the Birth of Welfare Economics. Princeton: Princeton University Press.

Lagueux, Maurice. 2010. "The Residual Character of Externalities." European Journal of the History of Economic Thought 17(4): 957-73.

Lane, Richard. 2014. The Nature of Growth: The Postwar History of the Economy, Energy, and the Environment. Dissertation, University of Sussex.

Leonard, Bryan, and Gary D. Libecap. 2019. "Collective Action by Contract: Prior Appropriation and the Development of Irrigation in the Western United States." Journal of Law and Economics 62(1): 67-115.

Maass, Arthur, Maynard M. Hufschmidt, Robert Dorfman, Harold A. Thomas, Jr., Stephen A. Marglin, and Gordon Maskew Fair. 1962. Design of Water-Resource Systems: New Techniques for Relating Economic Objectives, Engineering Analysis, and Governmental Planning. Cambridge, MA: Harvard University Press.

Marciano, Alain. 2013. "Why Market Failures Are Not a Problem: James Buchanan on Market Imperfections, Voluntary Cooperation, and Externalities." History of Political Economy 45(2): 223-54.

McDonald, John F. 2013. "Pigou, Knight, Diminishing Returns, and Optimal Pigouvian Congestion Tolls." Journal of the History of Economics Thought 35(3): 353-72.

McKean Roland N. 1958. Efficiency in Government through Systems Analysis: With Emphasis on Water Resources Development. New York: John Wiley \& Sons.

Meade, J.E. 1952. "External Economies and Diseconomies in a Competitive Situation." Economic Journal 62: 54-67.

Medema, Steven G. 2009. The Hesitant Hand: Taming Self-Interest in the History of Economic Ideas. Princeton: Princeton University Press.

Medema, Steven G. 2014a. "The Curious Treatment of the Coase Theorem in the Environmental Economics Literature, 1960-1979." Review of Environmental Economics and Policy 8(1): 39-57.

Medema, Steven G. 2014b. "1966 and all that: Codification, Consolidation, Creep, and Controversy in the Early History of the Coase Theorem." Journal of the History of Economic Thought 36(3): 271-303.

Medema, Steven G. 2019. "The Coase Theorem at Sixty." Working paper, Duke University.

Medema, Steven G. 2020a. '"Exceptional and Unimportant'? Externalities, Competitive Equilibrium, and the Myth of a Pigovian Tradition." History of Political Economy 52(1): 135-70.

Medema, Steven G. 2020b. Personal correspondence. May 20, 2020. 
Mills, Edwin S. 1966. "Economic Incentives in Air Pollution Control." In The Economics of Air Pollution, ed. by Harold Wolozin, pp. 40-50. New York: W.W. Norton \& Co.

Missemer, Antoine, Marion Gaspard, and Roberto Ferreira da Cunha. 2019. "Depreciation and Exhaustible Resources: Exploring Harold Hotelling's Twin Projects." Mimeo.

Montgomery, W. David. 1972. "Markets in Licenses and Efficient Pollution Control Programs." Journal of Economic Theory 5: 395-418.

Nishibayashi, Shogo. 2019. "A.V. Kneese's Water Quality Management Research (1960s), within the History of Environmental Economics. Journal of the History of Economic Thought 41(3): 411-31.

Ostrom, Vincent, and Elinor Ostrom. 1965. "A Behavioral Approach to the Study of Intergovernmental Relations." Annals of the American Academy of Political and Social Science 359: 137-46.

Papandreou, Andreas A. 1994. Externality and Institutions. Oxford: Oxford University Press.

Pearce, David. 2002. "An Intellectual History of Environmental Economics." Annual Review of Energy and the Environment 27: 57-81.

Pigou, A.C. 1932 [1962]. The Economics of Welfare, $4^{\text {th }}$ ed. London: MacMillan \& Co.

Porter, Theodore M. 1995. Trust in Numbers: The Pursuit of Objectivity in Science and Public Life. Princeton, NJ: Princeton University Press.

Roosevelt, Theodore. 1908. "Conservation as a National Duty." Speech, May $13^{\text {th }}$. https://voicesofdemocracy.umd.edu/theodore-roosevelt-conservation-as-a-national-dutyspeech-text/

Sandmo, Angmar. 2015. "The Early History of Environmental Economics." Review of Environmental Economics and Policy 9(1): 43-63.

Scitovsky, Tibor. 1954. "Two Concepts of External Economies." Journal of Political Economy 62: 143-51.

Scott, Anthony. 1955. "The Fishery: The Objectives of Sole Ownership." Journal of Political Economy 63(2): 116-24.

Singleton, John D. 2015. "Sorting Charles Tiebout." In Market Failure in Context, ed. by Alain Marciano and Steven G. Medema. Durham, NC: Duke University Press, pp. 199-226.

Solow, Robert M. 1971. "The Economist's Approach to Pollution and Its Control." Science 173: 498-503.

Stavins, Robert. 2011. "The Problem of the Commons: Still Unsettled after 100 Years." American Economic Review 101: 81-108. 
Steiguer, J. Edward de. 2006. The Origins of Modern Environmental Thought. Tucson: University of Arizona Press.

Stigler, George. 1946. Production and Distribution Theories. New York: Macmillan.

Taylor, Henry C. 1919. Agricultural Economics. New York: The Macmillan Co.

Teele, R.P. 1904. "The Organization of Irrigation Companies." Journal of Political Economy 12: $161-78$.

Teele, R. P. 1926. "The Financing of Non-Governmental Irrigation Enterprises." Journal of Land and Public Utility Economics 2(4): 427-40.

Tietenberg, T.H. 2006. Emissions Trading: Principles and Practice, $2^{\text {nd }}$ ed. Washington, DC: Resources for the Future.

Tietenberg, Tom. 2010. "Cap-and-Trade: The Evolution of an Economic Idea." Agricultural and Resource Economics Review 39(3): 359-67.

Viner, Jacob. 1932. "Cost Curves and Supply Curves." Zeitschrift Für National-ökonomie 3(1): 23-46.

Weisbrod, Burton A. 1961. Economics of Public Health: Measuring the Economic Impacts of Diseases. Philadelphia: University of Pennsylvania Press.

Weitzman, Martin L. 1974a. "Prices vs. Quantities." Review of Economic Studies 41(4): 477-91.

Weitzman, Martin L. 1974b. "Free Access vs. Private Ownership as Alternative Systems for Managing Common Property." Journal of Economic Theory 8(2): 225-34.

Young, Allyn A. 1913. "Review of Pigou's Wealth and Welfare." Quarterly Journal of Economics 27(4): 672-86.

Young, Allyn A. 1928. "Increasing Returns and Economic Progress." Economic Journal 38: 52742. 